\title{
Cervical Intraspinal Meningioma
}

National Cancer Institute

\section{Source}

National Cancer Institute. Cervical Intraspinal Meningioma. NCI Thesaurus. Code C5296.

A meningioma that arises from the meninges of the cervical region of the spinal cord. 